\title{
Effect of Hormone-Induced Premature Parturition on Hemoglobin Switching in Sheep
}

\author{
ANDREA HORVATH, ALDONA BUTKUS, RICHARD J. MACISAAC, LAUREN PONTEFRACT, \\ AND E. MARELYN WINTOUR \\ Department of Physiology and Howard Florey Institute of Experimental Physiology and Medicine, University of \\ Melbourne, Parkville, 3052, Victoria, Australia
}

\begin{abstract}
This study examines the effect of premature delivery on the switch from fetal $\left(\alpha_{2} \tau_{2}\right)$ to adult $\left(\alpha_{2} \beta_{2}\right)$ $\mathrm{Hb}$, in lambs in which premature parturition was induced by the intrafetal infusion of ACTH or corticotropin releasing hormone. Of $\mathbf{1 0}$ chronically cannulated ovine fetuses given ACTH at the rate of $79 \mathrm{ng} / \mathrm{min}$ for a $15 \mathrm{~min}$ period every 2 h starting at days $125(n=9)$ or $126(n=1)$ of gestation, three died in utero at days 131, 131, and 130 , respectively. The remaining seven were born alive at 133 \pm 1.6 days. Five control fetuses, treated with vehicle $(0.9 \%$ $\mathrm{NaCl}$, wt/vol) only were delivered at $149 \pm 2.7$ days of gestation, which is not significantly different from the duration of pregnancy in other chronically cannulated lambs in this flock. Hb switching, as measured by the globin synthesis ratio, $\beta / \alpha$, was complete at term in the control lambs. The $\beta / \alpha$ globin synthesis ratio of the prematurely delivered lambs was not accelerated by birth, and was similar to that of control fetuses of the same gestational age still in utero. The four lambs surviving premature birth more than 70 days did not complete the switch to normal adult $\mathrm{Hb}$ until after 220 days postconception. (Pediatr Res 24: 688-692, 1988)
\end{abstract}

\section{Abbreviations}

CRH, corticotrophin-releasing hormone

For most of gestation sheep fetal red blood cells contain a fetal $\mathrm{Hb}$, with two $\alpha$ and two $\tau$ globin chains. This fetal $\mathrm{Hb}$ has a higher oxygen affinity than does adult $\mathrm{Hb}$ with two $\alpha$ and two $\beta$ globins $(1,2)$. There are two genetic variants of adult $\mathrm{Hb}$ in adult sheep $\left(\beta^{\mathrm{A}}\right.$ and $\left.\beta^{\mathrm{B}}\right)$ which differ in at least seven amino acids in the globin chain (3-5). Sheep may be homozygous for either or heterozygous. In those animals carrying the $\beta^{\mathrm{A}}$ gene a third type of $\mathrm{Hb}\left(\beta^{\mathrm{C}}\right)$ is produced when sheep are made anemic $(6,7)$. This variant, linked to the $\beta^{\mathrm{A}}$ gene differs from $\beta^{\mathrm{A}}$ in having 141 rather than 145 amino acids in the globin chain, and a minimum of 18 substitutions in amino acid structure $(3,5)$.

The switch from fetal to adult $\mathrm{Hb}$ commences approximately 4 wk before term (142-152 days) and is complete by 170 days postconception at the latest $(1,2,8,9)$. When the capacity of reticulocytes to synthesize globin chains is assessed the switch is complete at term, but it is approximately 2 wk before all fetal

Received June 13, 1988; accepted August 4, 1988.

Supported by grants from the National Health and Medical Research Council of Australia to the Howard Florey Institute of Experimental Physiology and Medicine, and by a grant from the Sudden Infant Death Research Foundation of Australia.

Correspondence Dr. E. M. Wintour, Department of Physiology, University of Melbourne, Parkville, 3052, Victoria, Australia.
Hb disappears from neonatal blood (9). It was reported that in lambs carrying the $\beta^{\mathrm{A}}$ gene a small proportion of $\beta^{\mathrm{C}}(<15 \%$ of total $\beta$ ) appears transiently after birth and persists for several months (10). Many attempts have been made to influence the time of onset of the switch from fetal $(\tau)$ to adult $(\beta) \mathrm{Hb}$ but these have been largely unsuccessful $(8,9,11,12)$. Once commenced, the rate of the switching process has been shown to be able to be modulated. Hypophysectomy or bilateral adrenalectomy of the chronically cannulated fetus causes the completion of the switch to be delayed considerably $(8,9)$. In the adrenalectomized fetus replacement of cortisol in gradually increasing amounts returned the rate of adult $\mathrm{Hb}$ synthesis to normal (9).

An increase in fetal cortisol production precedes and indeed induces parturition at normal term in sheep (13). Premature parturition can be induced by the treatment of immature ovine fetuses with cortisol, ACTH, or CRF some $3 \mathrm{wk}$ or more before normal term $(14,15)$. These fetuses show accelerated lung maturation. The purpose of this study was to investigate the effect of premature activation of the fetal adrenal on $\mathrm{Hb}$ switching in the ovine fetus. The hypothesis was that premature parturition, induced by the fetal infusion of ACTH or CRF, would accelerate the completion of the switch from fetal to adult $\mathrm{Hb}$.

\section{MATERIALS AND METHODS}

A total of 54 blood samples $(1 \mathrm{ml})$ from 20 fetuses chronically cannulated as described previously $(16,17)$ was used to establish $\alpha, \beta$, and $\tau$ globin synthesis in normal intact animals from 103 days of gestation until term. Then 39 samples were collected from birth until 30 days postpartum, and three samples from one older lamb. Five of these fetuses received an infusion of sterile isotonic saline $(0.9 \% \mathrm{NaCl})$ from day 125 to 135 of gestation, in a protocol identical to that used for ACTH infusion. In 11 other animals an attempt was made to induce premature parturition by the intrafetal infusion of ACTH or CRH. Starting on day $125(n=9)$ or $126(n=1)$ of gestation, synthetic $\mathrm{ACTH}_{1-24}$ was infused as a $15-\mathrm{min}$ pulse $(79 \mathrm{ng} / \mathrm{min}$ at the rate of $1.9 \mathrm{ml} / \mathrm{h}$ ) every $2 \mathrm{~h}$ into the jugular veins of chronically cannulated fetuses until spontaneous parturition or fetal death in utero occurred.

Samples were also collected from one fetus or lamb delivered prematurely as the result of continuous intravenous infusion of ovine CRH, $2.4 \mu \mathrm{g} / \mathrm{h}$, as reported previously (15). A total of 19 samples was collected from these fetuses up until the time of birth. Then 46 samples were collected from the four surviving lambs over another 70-90 days. As a daily routine for all animals $1 \mathrm{ml}$ of fetal arterial blood was withdrawn for the measurement of blood gases and hematocrit. A total of $8 \mathrm{ml}$ blood was drawn daily during the hormone/saline infusion period for hormone assays (18). Fetal urine was drained from a bladder cannula into a sterile container for measurement of urine osmolality.

Globin synthesis/analysis. In all fetal and neonatal samples in 
which reticulocytes were present globin synthesis was measured; in those samples in which no reticulocytes were present the actual globin chains present in the sample were quantitated, after separation, by densitometry. All samples from one animal were analyzed by the same globin separation technique. Approximately equal numbers of both control and experimental samples were analyzed by each method. All samples were incubated with $\left[{ }^{3} \mathrm{H}\right]$ leucine $(0.05$ or $5.0 \mathrm{mCi}$, Amersham International, Bucks, U.K.) for $2 \mathrm{~h}$ at $37^{\circ} \mathrm{C}$, washed with $0.9 \%$ (wt/vol) $\mathrm{NaCl}$ and processed immediately or stored at $-80^{\circ} \mathrm{C}$. The higher concentration of $\left[{ }^{3} \mathrm{H}\right]$ leucine was required in the samples processed by the gel method (see below) to obtain adequate counts in the smaller aliquots of globin run in this system. When globin chains were to be separated by ion-exchange chromatography, hemolysates were prepared by the addition of distilled water, and stroma was removed by centrifugation at $3000 \mathrm{rpm}$ for $5 \mathrm{~min}$ at room temperature. Globin was prepared from stroma-free hemolysates by acid-acetone precipitation (19). In these samples the globin chains were separated by ion-exchange chromatography on CM52, using a $\mathrm{Na}_{2} \mathrm{HPO}_{4}$-urea buffer system at pH 6.7 (20). The majority of the globin chain separation was done by a modification of the method of Alter et al. (21) by electrophoresis on $0.75-\mathrm{mm}$ thick mini slab-gels (Bio-Rad Laboratories, Cambridge, MA). The samples were lysed and loaded in PAPS buffer $(0.5$ mg Pyromin Y; $1.74 \mathrm{ml}$ deionized $8 \mathrm{M}$ urea, $200 \mu 1$ 2-mercaptoethanol; $60 \mu \mathrm{l}$ Nonidet $\mathrm{P}-40$ ). The $10 \%$ resolving gel consisted of $1.67 \mathrm{ml}$ acrylamide: DATD T60\%: $\mathrm{C} 14.5 \% ; 0.5 \mathrm{ml}$ acetic acid; $7.38 \mathrm{ml} 8 \mathrm{M}$ deionized urea; $0.2 \mathrm{ml}$ Triton X-100; 0.265 $\mathrm{ml}$ deionized water. After degassing for $10 \mathrm{~min} 125 \mu 1$ of TEMED and $15 \mu 160 \%$ freshly prepared ammonium persulfate were added. The gels were poured, overlayed with electrophoresis buffer (5\% acetic acid) and allowed to polymerize overnight. The next morning the overlay was discarded, the well former inserted, and a stacking gel of $4.9 \%$ was poured and allowed to polymerize for $1 \mathrm{~h}$. The well former was removed, the wells carefully rinsed with $5 \%$ acetic acid, and preelectrophoresis carried out with the anode at the top for $60 \mathrm{~min}$ at $150 \mathrm{~V}$. The anode buffer was removed, the wells rinsed as above and filled with $10^{-1} \mathrm{M} 2$ mercaptoethanol, fresh electrophoresis buffer was added, and the second preelectrophoresis carried out for $60 \mathrm{~min}$ at $100 \mathrm{~V}$. The anode buffer was again discarded and the wells were thoroughly rinsed with $5 \%$ acetic acid before the samples ( $5 \mu 1$ lysate) and standards were applied to the appropriate wells. On addition of fresh anode buffer electrophoresis was performed at $30 \mathrm{~mA}$ until the dye marker reached the resolving gel, and then at $60 \mathrm{~mA}$ to the bottom of the gel. Electrophoresis was continued for an extra $5 \mathrm{~min}$. The gels were stained with $0.5 \%$ Serva Blue $\mathrm{G}$ for $30 \mathrm{~min}$ and destained in $7 \%$ acetic acid $/ 30 \%$ methanol. The globin bands were cut out and dissolved in $500 \mu 12 \%$ periodic acid overnight on a shaking platform. A total of $10 \mathrm{ml}$ of Hionic-fluor scintillation fluid was added to each sample and counting was performed on a Packard beta counter for a minimum of $10 \mathrm{~min}$ or until $10,000 \mathrm{cpm}$ accumulated. Hionic-fluor was obtained from United Technologies Packard, acetic acid and Nonidet P-40 from $\mathrm{BDH}$, methanol from Mallincrodt Inc., St. Louis, MO, and all other reagents from Bio-Rad.

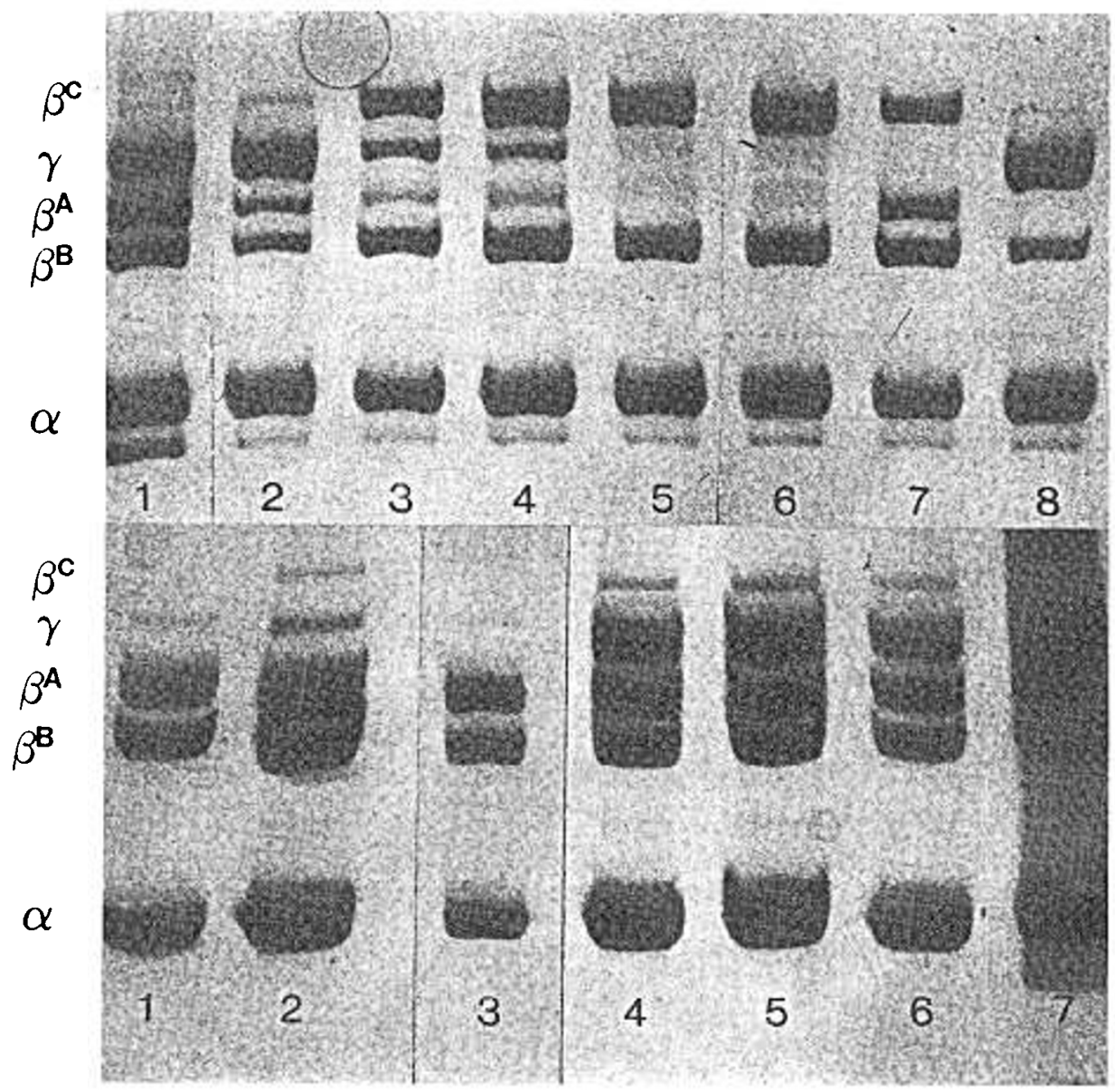

Fig. 1. Upper panel, pattern of globin separation in the gel-electrophoresis method described in the text. $l$, standard sample of sheep blood from a fetus heterozygous for $\beta^{\mathbf{A}}, \beta^{\mathbf{B}}$. 2, seven samples from one prematurely delivered lamb at (2) 154 , (3) 164 , (4) 168 , (5) 178 , (6) 185 , and (7) 220 days postconceptional age. As $\tau$ globin disappears $\beta^{\mathrm{A}}$ globin is completely replaced by $\beta^{\mathrm{C}}$ which is still present in significant amounts at day 220 . 8 , sample from fetus homozygous for $\beta^{\mathrm{B}}$ at 149 days postconception. Lower panel, globin separation in a lamb, heterozygous for $\beta^{\mathrm{A}} \beta^{\mathrm{B}}$, born at normal term (150 days) at (1) 210 , (2) 189 , (3) 175 , (4) $169,(5) 164,(6) 164$ days postconception. In well 6 half as much sample was loaded as in well 5 . In well 7 the standard sample is run. All $\tau$ had disappeared by this time and $\beta^{\mathrm{C}}$ appeared transiently between days 164 and 189 . 
Statistics. The values for experimental and control fetuses/ lambs were analysed by the unpaired Student's $t$ test.

\section{RESULTS}

Validation of method. The separation of the various sheep globins by electrophoresis are shown in Figure 1 for 2 sheep, heterozygous for $\beta^{\mathrm{A}}$ and $\beta^{\mathrm{B}}$. The upper panel shows the emergence and persistence of the $\beta^{\mathrm{C}}$ globin in the prematurely delivered lamb, while the lower panel shows the much more restricted expression of $\beta^{\mathrm{C}}$ in the normal term lamb.

Validation of the modified electrophoretic gel method as a useful globin protein assay was achieved by comparing the ratios of $\tau /(\tau+\beta)$ and $(\tau+\beta) / \alpha$ in the standard Clegg assay and the new method. Table 1 shows the results for six samples between the two methods.

The reproducibility of the new assay was tested by assaying the one sample six times. The mean value of the $\tau /(\tau+\beta)$ ratio was 0.70 and the coefficient of variation was $4 \%$. The mean value of the $(\tau+\beta) / \alpha$ ratio was 0.98 and the coefficient of variation was $5 \%$. In all assays results were not used unless the non- $\alpha$ - to $\alpha$-globin ratio was in the normal range, $0.8-1.2$, as described previously (9).

Outcome of pregnancies. Of the 10 fetuses infused with ACTH, eight were born alive $178 \pm 14 \mathrm{~h}$ after the commencement of the infusion, at $133 \pm 1.6$ days of gestation. The mean duration of pregnancy in this flock, for chronically cannulated fetuses is $149.6 \pm 2.7$ days $(22)$. Thus parturition in this study occurred 2-3 wk prematurely. Three fetuses died in utero on days 130 , 131 , and 131, respectively, of cord constriction. Of the live-born lambs four died at days 133-145 postconception of unknown causes. Three survived for more than 4 months, and two are currently alive. One lamb was born due to CRF infusion, at 135 days of gestation and survived for more than 4 months (15).

Birth weight of the premature lambs was $2.2 \pm 0.1 \mathrm{~kg}$ which was significantly less than than of normal full-term lambs, $3.1 \pm$ $0.2 \mathrm{~kg}(p<0.01)$.

During the period of $\mathrm{ACTH} / \mathrm{vehicle}$ infusion the blood gases and urine osmolalities of all fetuses in utero were in the normal range for unstressed fetuses in this laboratory (23). For the fetuses receiving $\mathrm{ACTH}$ the values were $-\mathrm{pH} 7.0 \pm 0.05, \mathrm{pCO}_{2} 42.5 \pm$ $2.7 \mathrm{~mm} \mathrm{Hg}, \mathrm{pO}_{2} 24.4 \pm 1.1 \mathrm{~mm} \mathrm{Hg}$, hematocrit $27 \pm 4 \%$, and fetal urine osmolality $119 \pm 14 \mathrm{mosmol} / \mathrm{kg}$ water. These values are the mean $\pm S D$ of the average daily values of 10 fetuses.

Arterial cannulae were not generally maintained in the lambs after birth, as the lambs remained with the ewes, and the risk of accidental hemorrhage was significant. In one prematurely delivered lamb and one control lamb blood gases were available for a restricted period. At postconception ages 154-176 days the $\mathrm{pO}_{2}$ was $67.6 \pm 6 \mathrm{~mm} \mathrm{Hg}$ in the premature lamb, compared with 77 $\pm 7 \mathrm{~mm} \mathrm{Hg}$ in the normal term lamb. In the age range 186-203 days the $\mathrm{pO}_{2}$ values for the premature and control lambs were $80 \pm 8$ and $85 \pm 9 \mathrm{~mm} \mathrm{Hg}$, respectively.

In Figure 2 there is shown the degree of adult $\mathrm{Hb}$ synthesis, as characterized by the $\beta / \alpha$ globin ratio for the control group and

Table 1. Comparison of globin synthesis ratios by two methods*

\begin{tabular}{cccccc}
\hline & \multicolumn{2}{c}{$\tau /(\tau+\beta)$} & & \multicolumn{2}{c}{$(\tau+\beta) / \alpha$} \\
\cline { 2 - 3 } \cline { 5 - 6 } Sample & $\mathrm{A}$ & $\mathrm{B}$ & & $\mathrm{A}$ & $\mathrm{B}$ \\
\hline 1 & 0.94 & 0.86 & & 1.23 \\
2 & 0.96 & 0.87 & & 1.17 & 1.24 \\
3 & 0.93 & 0.84 & & 1.20 & 1.18 \\
4 & 1.00 & 0.80 & & 1.10 & 1.01 \\
5 & 0.28 & 0.34 & & 1.05 & 1.16 \\
6 & 0.06 & 0.12 & & 0.80 & 0.99
\end{tabular}

* Globin synthesis ratios in six individual blood samples from fetal sheep determined by $\mathrm{A}$, the ion exchange method $(19,20)$ and $\mathrm{B}$, by the elecrophoresis method described in "Materials and methods."

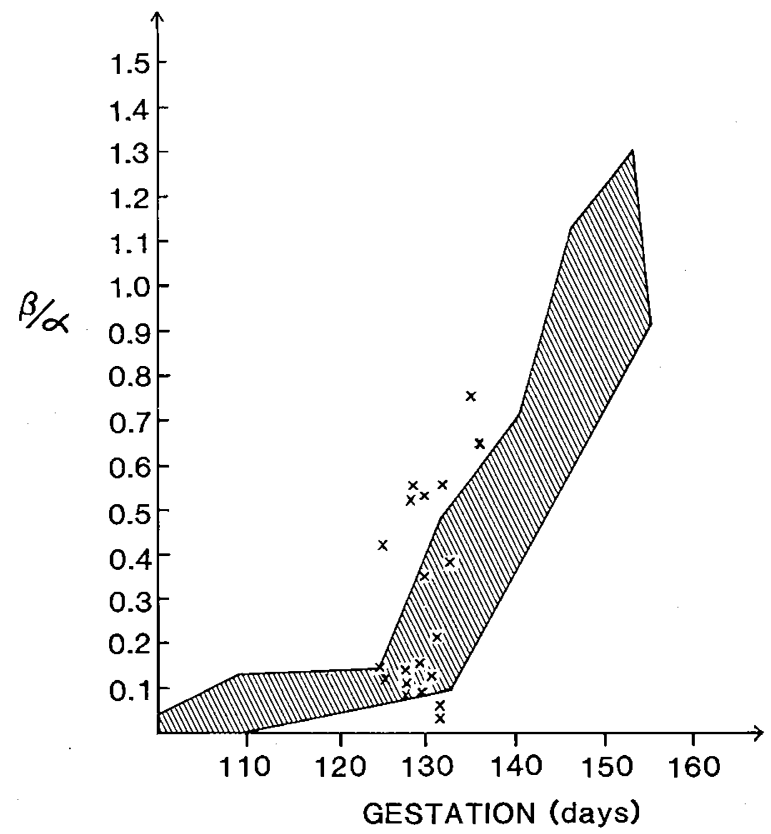

Fig. 2. Normal increase in adult $\mathrm{Hb}$ as measured by the $\beta / \alpha$ globin synthesis ratio in control fetuses (hatched area) and the ratios of fetuses treated with ACTH/CRH in the (premature) perinatal period.

the prematurely delivered group about the time of delivery, or fetal death in utero. The shaded area depicting the normal range was drawn from the mean $\pm 2 \mathrm{SD}$. It can be seen that the values of the ACTH-treated fetuses lie predominantly within the normal range. The mean value of the $\beta / \alpha$ ratio for these animals at $130-$ 140 days postconception was $0.45 \pm 0.24(n=9)$ which was not significantly different from that of the control fetuses till in utero at that age, $0.34 \pm 0.14(n=10)$. Both of these values were significantly lower than the $\beta / \alpha$ ratio at birth in the control animals, of $0.94 \pm 0.18$ (11).

Of the four fetuses which survived for a prolonged period after premature parturition, two were homozygous for $\beta^{\mathrm{A}}$ and two were homozygous for $\beta^{\mathrm{B}}$. The extent of adult $\mathrm{Hb}$ synthesis after birth is shown by the $\beta / \alpha$ globin ratio in Figure 3. It can be seen that the switch to full adult $\mathrm{Hb}$ synthesis was not completed at the normal time. In the two $\beta^{\mathrm{B}}$ lambs the fetal $\tau$ globin persisted for an extended period. There was an unusual oscillation in the amount of adult $\mathrm{Hb}$. In the two $\beta^{\mathrm{A}}$ lambs the $\tau$ globin synthesis ceased but abnormally high levels of $\beta^{\mathrm{C}}$ globin were found. The proportion of $\beta^{\mathrm{C}}$, as a percentage of all $\beta$ globin, is shown in Figure 4. It can be seen that $\beta^{\mathrm{C}}$ was present from 130-220 days postconception, in amounts from $2-50 \%$. In contrast, in 28 samples from heterozygous lambs born at normal term, $\beta^{\mathrm{C}}$ appeared in only 10 samples, from 158-189 days, and never exceeded $3 \%$ of the total $\beta$ globin.

\section{DISCUSSION}

The modified method for separation of globin chains described in this paper has the following advantages over the method of Alter et al. (21). Better separation of the various globin chains of sheep is possible; the amount of sample that is required is $1 \mu \mathrm{g}$, allowing multiple analyses of the one hemolysate; the gel is readily solubilized for counting of the ${ }^{3} \mathrm{H}$-globin in a liquid scintillation spectrometer. Reproducibility is acceptable, and the accuracy is similar to that obtained using the ion exchange column $(19,20)$ which requires much larger amounts $(\mathrm{mg})$ of globin for analysis.

In all fetuses the initiation of $\beta$-globin synthesis had occurred before the ACTH or CRH infusion began. This was both expected and desirable as it has been shown previously that the absence or presence of cortisol did not affect the onset of the 
switch from fetal to adult $\mathrm{Hb}$ (9). The onset of switching seems to be related to a developmental program inherent in the erythropoietic cell line (12). This may be conditioned by the number of cell divisions that stem cells undergo. The slightly accelerated onset of switching seen when fetal erythropoietic tissue was transplanted into irradiated adult sheep has been explained by the increased rate of red cell production which occurs in such conditions $(11,12)$.

Although the premature birth of some viable lambs could be achieved by the protocols used there was no acceleration of the completion of the switch from fetal to adult globin synthesis.

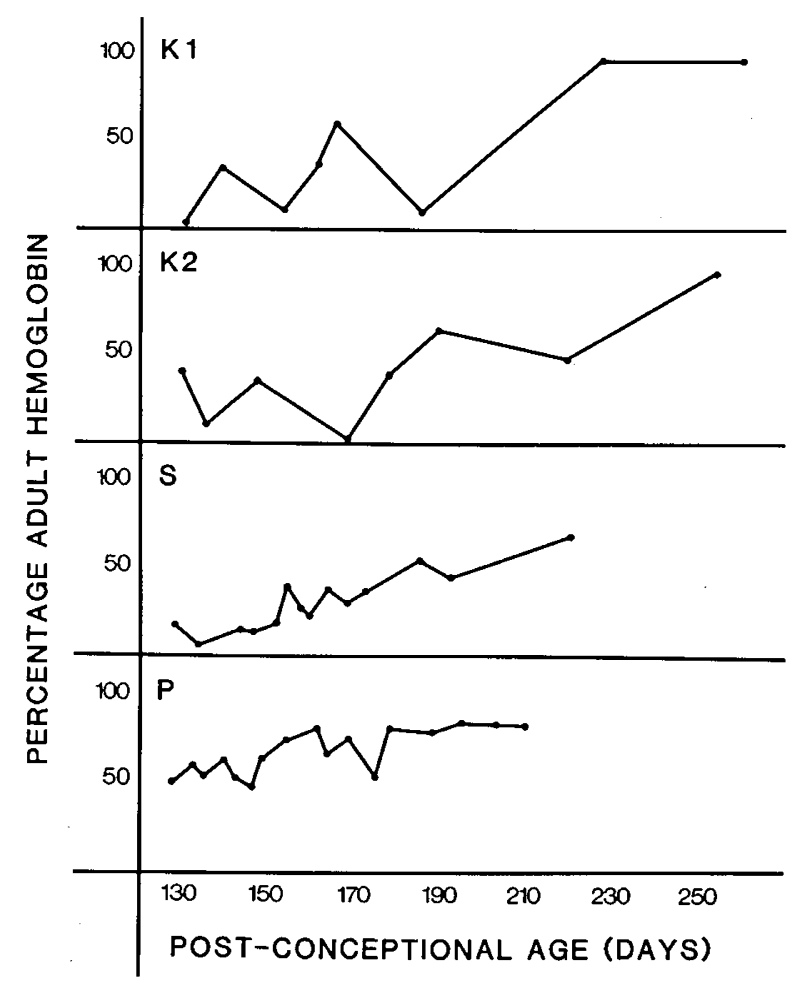

Fig. 3. Percent adult $\mathrm{Hb}$ as determined by the $\left(\beta^{\mathrm{A}}+\beta^{\mathrm{B}}\right) /(\beta+\tau)$ ratio (for lambs $\mathrm{P}$ and $\mathrm{S}$ ) and by the $\beta^{\mathrm{B}} /(\beta+\tau)$ ratio for lambs $\mathrm{K}_{1}$ and $\mathrm{K}_{2}$ ). These four lambs were born prematurely as the result of hormone treatment as described. The normal adult ratio of $100 \%$ was not achieved until more than 220 days postconceptional age.
The cortisol values rose to ones similar to those seen in normal term fetuses (MacIsaac RJ, personal communication), although over a shorter time period and at an earlier postconceptional age. There are a number of reasons why the switch might not be accelerated. As sheep erythroid progenitors require 3-6 days for maturation the period of 6-8 days of ACTH infusion may have been too short to see the effect. However, inasmuch as globin synthesis rather than content was measured, this is unlikely to be a major problem.

For a steroid such as cortisol to exert a biologic effect on gene expression there must be receptors in the target tissue, the inducible genes must be contained in DNAase-sensitive domains, and appropriate interactions between the chromosomal gene and the nuclear matrix appear essential $(24,25)$. Receptors for ${ }^{3} \mathrm{H}$ dexamethasone, but not for aldosterone, have been found in the bone marrow and liver of fetuses at 123-130 days of gestation (Wintour and Funder, unpublished results). In midgestation only the $\tau$ gene is in the conformation associated with active transcription, whereas both $\beta$ and $\tau$ genes are in the DNAasesensitive conformation in the bone marrow of newborn lambs (26). As $\beta$-synthesis had begun before the hormone infusions started, presumably the $\beta$-gene was in the appropriate conformation by this time. As the $\tau$-gene remains in the active conformation the possibility exists that glucocorticoids can also affect translation of the globin mRNA, as demonstrated for $\alpha$ - and $\beta$ genes in differentiating Friend erythroleukemia cells $(27,28)$. Even if the previously demonstrated effect of cortisol is not on the globin genes directly but on some intermediate cell that produces a trans-acting factor, these arguments still apply.

It has been shown that chromatin structure in the region of the three goat $\beta$-globin genes, $\beta^{\mathrm{F}}, \beta^{\mathrm{C}}$, and $\beta^{\mathrm{A}}$, changes in a manner which parallels their developmentally regulated expression (29). Further mapping of the fine structure of the chromatin of the goat $\beta^{\mathrm{F}}$ gene has delineated two further sites which differ in accessibility to specific restriction enzymes from corresponding sites on the goat $\beta^{\mathrm{C}}$ and $\beta^{\mathrm{A}}$ genes which were not expressed in fetal erythropoietic liver tissue (30). More studies are required in the fetal sheep erythroid tissues to help us to understand the possible time of action of trans-acting factors that may regulate the extent of expression of fetal and adult globin genes.

In the four premature lambs that survived for prolonged periods after birth normal adult $\mathrm{Hb}$ synthesis was not found until more than 220 days postconception. In the two lambs of the $\beta^{\mathrm{B}}$ genotype the $\tau$-globin persisted for a prolonged period. The unusual oscillation of the amount of adult $\mathrm{Hb}$ may reflect the instability of the gene expression when it has lost the normal

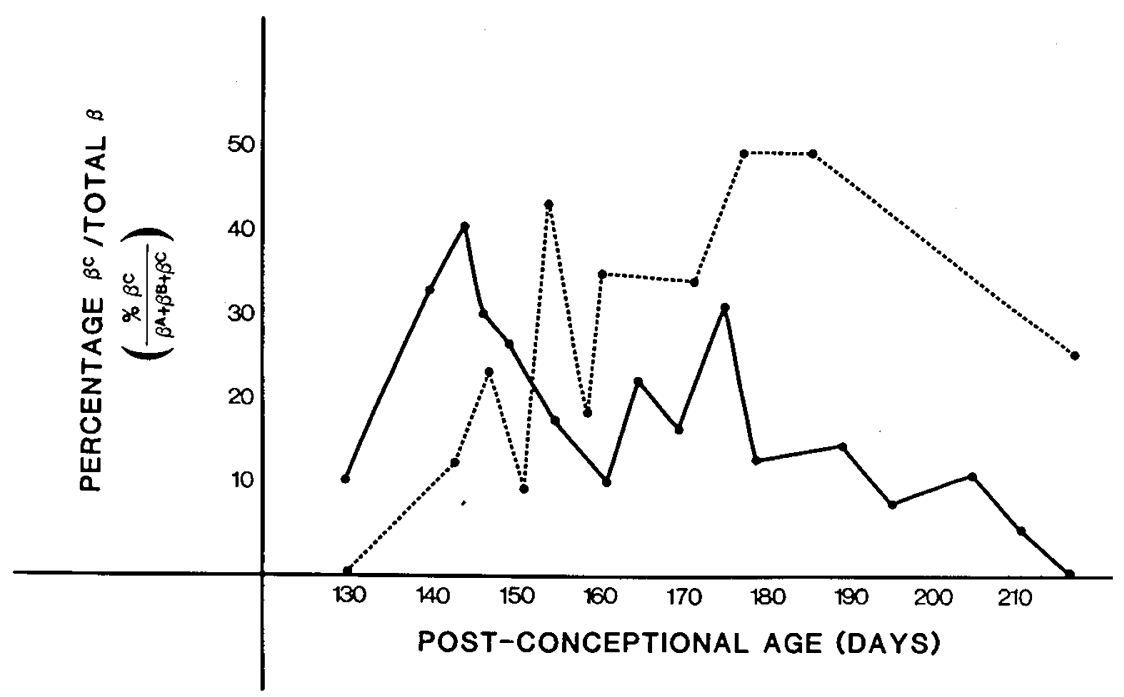

Fig. 4. Percentage of $\beta^{\mathrm{B}}$ of the non- $\alpha$-globin in two fetuses, heterozygous for $\beta^{\mathrm{A}} \beta^{\mathrm{B}}$, born prematurely as the result of hormone treatment as described. $\beta^{\mathrm{C}}$ was present at more than normal levels for an extended period after birth. 
modulating effect of cortisol. In the two lambs of the $\beta^{\mathrm{A}}$ genotype $\tau$-globin synthesis ceased but there was expression of the $\beta^{\mathrm{C}}$ gene at abnormally high levels for an abnormally long period of time. It is of interest that the order of decreasing oxygen affinity of sheep $\mathrm{Hb}$ is $\mathrm{Hb}-\mathrm{F}, \mathrm{Hb}-\mathrm{A}_{\mathrm{C}}, \mathrm{Hb}-\mathrm{A}_{\mathrm{B}}$, and $\mathrm{Hb}-\mathrm{A}_{\mathrm{A}}$ (31). Thus the premature lambs all expressed a $\mathrm{Hb}$ of higher than normal oxygen affinity in the perinatal period. Wardrop et al. (32) described the clinical features of tachycardia, tachypnea, dyspnea, and feeding difficulties in $53 \%$ of babies born at less than $32 \mathrm{wk}$ of gestation. They ascribe these findings to the high oxygen affinity of the fetal $\mathrm{Hb}$ in these babies.

These experiments are being pursued because they may provide more evidence that exposure of the fetal lamb to an increasing concentration of cortisol at a critical time (135-145 days) is crucial for the normal completion of the $\mathrm{Hb}$ switch. The concept of critical time periods is one familiar to developmental biologists. So far there has been one report on a "time" gene. In mice a linkage has been found between a single gene (Prn-i) that affects scrapie incubation period and the prion which is the infectious agent (33).

Endocrine disturbances that affect the rate of $\mathrm{Hb}$ switching in man have also been described. Babies born to diabetic mothers had a mean $\beta$-globin synthesis of $14.8 \%$ at $36-38$ wk of gestation compared with $44.6 \%$ in babies of healthy mothers, at the same gestational age (34). A significantly higher than normal proportion of fetal $\mathrm{Hb}$ has been reported in babies, more than 55 weeks postconception, who have died a sudden infant death or cot death (35). These clinical studies emphasize the importance of understanding the factors modulating the expression of globin genes.

\section{REFERENCES}

1. Bard H, Battaglia FC, Makowski EL, Meschia G 1972 The synthesis of fetal and adult haemoglobin in sheep during perinatal period. Proc Soc Exp Biol 139:1148-1150

2. Wood WG, Nash J, Weatherall DJ, Robinson JS, Harrison FA 1979 The sheep as an animal model for the switch from fetal to adult hemoglobins. In: Stamatoyannopoulos G, Nienhuis AW (eds) Cellular and Molecular Regulation of Hemoglobin Switching? Grune and Stratton, New York, pp 153167

3. Boyer SH, Hathaway P, Pascaro F, Orton C, Bordley J, Naughton MA 1966 Hemoglobins in sheep: multiple differences in amino acid sequences of three beta-chains and possible origins. Science 153:1539-1543

4. Huisman THJ, Reynolds CA, Dozy AM, Wilson JB 1965 The structure of sheep hemoglobins $I$. The amino acid compositions of the $\alpha$ and $\beta$ chains of the hemoglobins A, B and C. J Biol Chem 240:2455-2460

5. Wilson JB, Edwards WC, McDaniel M, Dobbs M, Huisman THJ 1966 The structure of sheep hemoglobins II The amino acid composition of the tryptic peptides of the non- $\alpha$ chains of hemoglobins A, B, C and F. Arch Biochem Biophys 115:385-400

6. Blunt MH, Evans JV 1963 Change in the concentration of potassium in the erythrocytes and in hemoglobin type in Merino sheep under a severe anemic stress. Nature 200:1215-1216

7. Van Vliet $G$, Huisman THJ 1964 Changes in the haemoglobin types of sheep as a response to anemia. Biochem $\mathrm{J}$ 93:401-409

8. Wood WG, Pearce K, Clegg JB, Weatherall DJ, Robinson JS, Thorburn GD, Dawes GS 1976 The switch from fetal to adult hemoglobin synthesis in normal and hypophysectomised sheep. Nature 264:799-801

9. Wintour EM, Smith MB, Bell RJ, MacDougall JG, Cauchi MN 1985 The role of fetal adrenal hormones in the switch from fetal to adult globin synthesis in the sheep. J Endocrinol 104:165-170

10. Huisman TJH, Lewis JP, Blunt MH, Adams HR, Miller A, Dozy AM, Boyd
EM 1969 Hemoglobin C in newborn sheep and goats: a possible explanation for its function and synthesis. Pediatr Res 3:189-198

11. Bunch C, Wood WG, Weatherall DJ, Robinson JS, Corp MJ 1981 Haemoglobin synthesis by fetal erythroid cells in an adult environment. $\mathrm{Br} \mathrm{J}$ Haemato 49:325-336

12. Wood WG, Bunch C, Kelly S, Gunn Y, Breckon G 1985 Control of haemoglobin switching by a developmental clock? Nature 313:320-323

13. Thorburn GD, Challis JRG 1979 Endocrine control of parturition. Physiol Rev 59:863-918

14. Liggins GC 1968 Premature parturition after infusion of corticotrophin or cortisol into fetal lambs. J Endocrinol 42:323-329

15. Wintour EM, Bell RJ, Carson RS, MacIsaac RJ, Tregear GW, Vale W, Wang X-M 1986 Effect of long-term infusion of ovine corticotrophin-releasing factor in the immature ovine fetus. J Endocrinol 111:469-475

16. Brown EH, Coghlan JP, Hardy KJ, Wintour EM 1978 Aldosterone, corticosterone, cortisol, 11-deoxycortisol and 11-deoxycorticosterone in the blood of chronically cannulated ovine fetuses: effect of ACTH. Acta Endocrinol 88:364-374

17. Lingwood BE, Hardy KJ, Horacek I, McPhee ML, Scoggins BA, Wintour EM 1978 The effects of antidiuretic hormone on urine flow and composition in the chronically cannulated ovine fetus. Q J Exp Physiol 63:315-330

18. MacIsaac RJ, Horvath AP, Wintour EM 1987 Induction of premature parturition in sheep by pulsatile ACTH infusion. Proceedings of the 5th Australian Perinatal Congress, 6(a) (abstr)

19. Weatherall DJ, Clegg JB, Naughton MA 1965 Globin synthesis in thalassemia: an in vitro study. Nature 205:1061-1065

20. Clegg JB, Naughton MA, Weatherall DJ 1966 Abnormal human haemoglobins, separation and characterization of the $\alpha$ and $\beta$ chains by chromatography, and the determination of two new variants, $\mathrm{Hb}$ Chesapeake and $\mathrm{Hb} \mathrm{J}$ (Bangkok). J Mol Biol 19:91-108

21. Alter BP, Goff SC, Efremov GD, Gravely ME, Huisman THJ 1980 Globin chain electrophoresis: a new approach to the determination of the $G_{\tau} / A_{\tau}$ ratio in fetal hemoglobin and to studies of globin synthesis. $\mathrm{Br} \mathrm{J}$ Haematol 44:527-534

22. MacIsaac RJ, Bell RJ, McDougall JG, Tregear GW, Wang X-M, Wintour EM 1985 Development of the hypothalamic- pituitary axis in the ovine fetus: ontogeny of action of action of ovine corticotropin-releasing factor. J Dev Physiol 7:329-338

23. Wintour EM, Bell RJ, Congiu M, MacIsaac RJ, Wang X-M 1985 The value of urine osmolality as an index of stress the ovine fetus. Q J Exp Physiol 7:347-354

24. O'Malley BW 1984 Steroid hormone action in eucaryotic cells. J Clin Invest $74: 307-312$

25. King RJB 1987 Structure and function of steroid receptors. J Endocrinol 114:341-349

26. Young NS, Benz EJ, Kantor JA, Kretschmer P, Nienhuis AW 1978 Hemoglobin switching in sheep: only the $\tau$ gene is in the active conformation in fetal liver but all the $\beta$ and $\tau$ genes are the active conformation in bone marrow. Proc Nat1 Acad Sci USA 75:5884-5888

27. Lo S-C, Aft R, Ross J, Mueller GC 1978 Control of globin gene expression in differentiating friend leukemia cells. Cell 15:447-453

28. Papaconstantiou J, Stewart JA, Rabek JP, McClintok PR, Wong EY 1983 Glucocorticoids inhibit the coordinated translation of $\alpha$ and $\beta$-globin mRNAs in Friend erythroleukemic cells. Arch Biochem Biophys 227:542551

29. Lingrel JB, Townes TM, Shapiro SG, Spence SE, Liberator PA, Wernke SM 1983 Organisation, structure and expression of the goat globin genes. In: Stammatoyannopoulos G, Nienhuis AW, (eds) Globin Gene Expression and Hemopoietic Differentiation. Alan R. Liss, New York, pp 131-139

30. Liberator PA, Lingrel JB 1987 Chromatin fine structure mapping of the goat $\beta^{\mathrm{F}}$ gene in fetal erythroid tissue. Mol Cell Biol 7:2772-2782

31. Huisman THJ, Kitchens J 1968 Oxygen equilibria studies of the hemoglobins from normal and anemic sheep and goats. Am J Physiol 215:140-146

32. Wardrop CAJ, Holland BM, Veale KE, Jones JG, Gray OP 1978 Nonphysiological anaemia of prematurity. Arch Dis Child 53:855-860

33. Carlson GA, Kingsbury DT, Goodman PA, Coleman S, Marshall ST, DeArmond S, Westaway D, Prusiner SB 1986 Linkage of prion protein and scrapie incubation time genes. Cell 46:503-511

34. Perrine SP, Greene MF, Faller DV 1985 Delay in fetal globin switch in infants of diabetic mothers. N Engl J Med 312:334-338

35. Giulian GC Gilbert EF, Moss RL 1987 Elevated fetal hemoglobin levels in sudden infant death syndrome. N Engl J Med 316:1122-1126 